\title{
The Influence of Budget Planning, Performance Measurement System and Budget Evaluation on the Performance of the Directorate General of Defense Planning
}

\author{
Guntur Eko Saputro ${ }^{1}$, Riki Firmansyah ${ }^{2}$, Meirinaldi ${ }^{3}$ \\ \{Gunturekosaputroarm95@gmail.com ${ }^{1}$, meirinaldi.2505@gmail.com ${ }^{3}$ \} \\ Universitas Pertahanan $^{1,2}$, Universitas Borobudur ${ }^{3}$
}

\begin{abstract}
The defense budget is an important resource in the development of defense forces, with the defense budget forming the performance of the Directorate General of Defense Planning. Performance is a management tool for improving the quality of decision making and accountability. In order to create an accountable government, it is necessary to know how the budget planning affects performance measurement and budget evaluation on the performance of the ministry of defense. A quantitative methodology is utilized to decide the effect of the elements being assessed. The discoveries of this examination are there is a connection between each huge and positive variable of financial plan arranging, execution estimation and spending plan assessment on the exhibition of the Directorate General of Defense Planning with SPSS devices. The created model can be seen from $\mathrm{R}$ squere 7.40 , which 74 percent of the whole model can be explained by the model.
\end{abstract}

Keywords: Defense Budget Evaluation; Performance; Influence; Defense Budget Planning; Performance Measurement Systems

\section{Introduction}

Indonesia has the state foundation Pancasila and the Republic of Indonesia's Constitution of 1945 (UUD NRI, 1945). The Republic of Indonesia's public interest, as expressed in the preface to the 1945 Constitution, is to advance public government assistance, teach the country's life, and aid the execution of world request. This national interest becomes a reference in the formulation and determination of a national security strategy. National security is a prerequisite to carry out national development in order to attain national objectives. Policy in the defense sector is closely related to the results of economic development. Economic development has an impact on increasing income for both the community and the government which will have an impact on welfare. Defense policy regulates the empowerment of potential defense resources [1].

Efforts to realize economic prosperity by considering state defense and the source of its financing are the goals that defense economics is trying to achieve. Defense economics studies the choices made by the government for the allocation of economic resources in order to meet 
economic and defense needs. and national security [2]. Non-military defense is a state defense force that is built within the framework of national development to achieve national welfare and is prepared to face non-military threats [3].

The development of military power is necessary to achieve minimal strength. This development aims to support domestic defense tasks, namely overcoming conflicts and maintaining The Republic of Indonesia's territorial integrity, as well as the outside / frontier boundaries and islands, are protected [4]. However, efforts to develop these strengths are faced with the problem of limited resources, including national resources. The defense budget is an important resource in developing the defense force. The Routine spending, goods spending, and capital spending make up the structure of military spending in the state budget [5]. In conditions of There is no consensus on security stability, strategic industrial growth, or macroeconomic stability; it is unclear what kind of defense security expenditure structure transformation is required to encourage sustainable economic growth and reduce income inequality as a potential threat to national defense and security [6].

Financial problems cannot be separated from the problem of corruption. The primary adversary of this country is corruption. Corruption, on the other hand, is a different kind of battlefield than the combat terms we're used to. This is a battle that takes place without the use of weapons, soldiers, or territories. This fight is fought not with firearms, but with the temptations of materialism, which target the human conscience. Corruption is a serious problem. endanger Indonesia's economic development, as well as make the community poor. Corruption has resulted in the destruction of the nation's and state's life order in Indonesia [7]. In economic theory, defense is often a classic example of pure public good. With its nonexcludable and non-rivalry character, the defense can only be provided by the government [8].

Large budget values should be followed by good performance as well. While the effectiveness factor can be viewed from the budget, it must be able to provide appropriate benefits or in accordance with the plans that have been determined by the Institution [9]. The capacities did by the public authority can be completed through financial strategy (with one of its accentuations) through government use or spending approaches. From here, the public authority through its strategies can cause spending to get labor and products to suit the necessities of the public government merchandise/administration acquisition instrument [10].

The low degree of government assistance, unreasonable financial development, and deficient improvement of monetary areas are the principle challenges in Indonesia's financial turn of events [11]. The development of military power is necessary to achieve minimal strength. This development aims to support domestic defense tasks, namely overcoming conflicts and maintaining the Republic of Indonesia's territorial integrity, including the protection of the country's outermost / frontier boundaries and islands. However, efforts to develop these strengths are faced with the problem of limited resources, including national resources. According to Anggoro Kusnanto, the defense budget is an important resource in developing the defense force [1]. Military and economy are two factors that can sustain the strength of a nation, where it can be seen from the nation's economic growth [12].

\section{Material and Methods}

This review is a quantitative report. Quantitative examination techniques are utilized to check out explicit populaces or tests, accumulate information utilizing research instruments, and break down factual information to assess speculations. A test review was utilized, fully intent on clarifying and testing thoughts concerning the connection between factors [13]. This 
research was conducted at the Directorate General of Defense Planning of the Ministry of Defense with the aim of obtaining data regarding budget planning, performance measurement, budget evaluation and performance of the Directorate General of Defense Planning.

Methodology for gathering data, a poll was used to gather information for this exploration. The specialist enquired about the factors that would be estimated in a survey. The survey was an information assortment strategy that included giving respondents a bunch of inquiries or composed inquiries to address [14]. The research instrument used was a type of questionnaire data. The questionnaire is used to measure budget planning variables (X1), performance measurement (X2), and budget evaluation (X3) on organizational performance (Y).

a) Validity test

The instrument that is distributed to respondents contains questions that come from the conception of the variables being studied. A If a measurement scale does what it's supposed to do and measures what it's supposed to measure, it's deemed valid. should be measured. Validity and reliability testing was carried out at the earliest before other analyzes [15].

b) Reliability Test

Reliability shows the consistency and stability of a score or measurement scale [15].

Reliability test to determine the level of confidence in the results of respondents' answers to the given instrument. After the validity test is carried out, the instrument is tested for its reliability level

c) Hypothesis testing

The theory is tried utilizing numerous straight relapse investigation. As indicated by Gujarati, relapse examination is a review that shows the reliant variable's (bound) reliance on at least one autonomous (free) factors determined to gauge or potentially foreseeing the populace normal or normal worth of the reliant variable dependent on the autonomous variable's known worth [16].

The coefficient of determination is a measurement of how well a model can explain variance in the dependent variable. The coefficient of determination is calculated using the method:

a) F test / A simultaneously significant test is a method of determining the significance of two or more variables at the same time.

b) The F factual test is utilized to check whether all of the free factors in a model combinedly affect the reliant variable [15].

c) $T$ test / partial significance test.

d) The measurable test is utilized to perceive how much every free factor adds to the variety in the reliant variable.

In this section, the author describes the steps at the time of conducting the research. The research method used is presented in detail to enable the reader to evaluate the method, reliability, and validity of the research findings. It is recommended that the research method be conveyed in a straightforward and concise manner.

\section{Results and Discussion}

Data analysis was conducted to answer the research objectives through four stages, namely: descriptive analysis, validity test, reliability test and hypothesis testing. Data SPSS 26 was used to conduct the findings in this research. The design and control system are dependent on the organizational context in which the control is implemented [17]. The results of research 
conducted in conjunction with Kusuma's research are: (1) Budget targets that are clear have a favorable impact on income and expenditure budgeting accuracy. (2) The accuracy of the income and expenditure budget is influenced by organizational dedication. (3) Variability in the environment has a detrimental impact on income and expenditure budget accuracy [18].

Elucidating examination serves to give an outline or depiction of the respondents' responses to the assertions introduced in the survey in every factor. Descriptive analysis of the performance variable $(\mathrm{Y})$, states that most of the respondents chose to strongly agree with the statement "Output resulting from activities is in accordance with the expected target" with the highest average value of the other statements, namely 4.30. Descriptive analysis of the Budget Planning variable (X1) most of the respondents chose to agree with the statement "There is continuity between planning and the activities to be carried out" with the highest average value of the other statements, namely 4.44. Descriptive analysis of the Performance Measurement System (X2) variable most of the respondents chose to agree with the statement "Employee performance targets are part of the institutional target" with the highest average value of the other statements, namely 4.15 . Performance measurement can be influenced by first, the level of growth and energy of a person who will think and operate more maturely, as far as trust, a more adult populace will be trusted in excess of a more youthful culture. an individual whose development level isn't adequately high. The more mature someone in thinking and working will minimize errors in decision making which will ultimately improve organizational performance [19], Education provides knowledge not only directly with the implementation of tasks, but also the foundation for self -development and the ability to utilize all the facilities that exist around us for the smooth implementation of tasks [20].

Descriptive analysis of the Budget Evaluation variable (X3) is based on understanding evaluation. Evaluation is an assessment carried out on the budget that has been prepared and knowing how much irregularities have occurred can be traced back to the budget executor who is responsible [21]. Most of the respondents chose to agree with the statement "Budget evaluation provides benefits to many parties in the organization" with the highest average value of the other statements, namely 4.33 .

\subsection{Validity test}

The validity test uses the product moment correlation and to simplify the analysis the SPSS 26 application is used. The validation test's results can be compared to the table's $r$ value. From the results of SPSS data processing, the analysis states that all statements from all variables are valid to be processed into research data.

\subsection{Reliability Test}

Dependability shows the consistency and steadiness of a score or estimation scale [15]. Reliability test to determine the level of confidence in the results of respondents' answers to the instruments given. The Cronbach Alpha technique was employed in this study for reliability analysis. and the calculations used the help of SPSS 26.

Table 1. Reliability Test Results

\begin{tabular}{lccc}
\hline \multicolumn{1}{c}{ Variable } & Cronbach Alpha & Alpha & Conclusion \\
\hline Performance $(\mathrm{Y})$ & 0,929 & 0,60 & Reliable \\
Budget Planning $\left(\mathrm{X}_{1}\right)$ & 0,876 & 0,60 & Reliable \\
Performance Measurement System $\left(\mathrm{X}_{2}\right)$ & 0,746 & 0,60 & Reliable \\
Budget Evaluation $\left(\mathrm{X}_{3}\right)$ & 0,796 & 0,60 & Reliable \\
\hline
\end{tabular}

Source: data processed by researchers (2020) 
From the results of SPSS data processing, the analysis states that the question items of all these variables are reliable and can be used in research.

\subsection{Classic Assumption test}

\subsection{Test for Normalcy}

The ordinariness test is utilized to check whether the puzzling or remaining factors in a relapse model have a typical dissemination. Measurable tests are utilized to approve the spread of ordinariness utilizing the Kolmogorov-Smirnov calculation in the trial of ordinariness. The ordinariness test is utilized to decide if the residuals are typically appropriated since the Kolmogorov-Smirnov esteem is more noteworthy than the table worth. The remaining isn't routinely dispersed if the Kolmogorov-Smirnov esteem is more modest than the table worth. On the off chance that the sig esteem is bigger than $5 \%$, the remaining spreads are viewed as average.

Table 2. Normality Test Results

\begin{tabular}{cccc}
\hline & \multicolumn{3}{c}{ Kolmogorov-Smirnov } \\
& Statistic & df & Sig. $^{\text {a }}$ \\
\hline Unstandardized Residual & .099 & 79 & .054 \\
\hline Source: data processed by researchers & $(2020)$
\end{tabular}

From table 2, the results of the normality test above show that the statistical value of 0.099 or the sig value of 0.054 or $5.4 \%$ is greater than the $\alpha$ value of $5 \%$, As a result, the residuals appear to be evenly distributed.

\subsection{Heteroscedasticity Test.}

The heteroscedasticity test decides if there is a disparity of fluctuation between the residuals of one perception and the residuals of one more in the relapse model. A decent relapse model is homoscedastic, implying that the difference of the residuals starting with one perception then onto the next is steady. The Glesjer test was utilized to distinguish the presence of heteroscedasticity. The accompanying table 3 shows the aftereffects of the heteroscedasticity test:

\begin{tabular}{lcc}
\multicolumn{3}{c}{ Table 3. Heteroscedasticity } \\
\multicolumn{1}{c}{ Model } & t & Sig. \\
\hline (Constant) & 1.245 & .217 \\
budget planning & 2.413 & .018 \\
performance measurement & -.195 & .846 \\
budget evaluation & -2.032 & .046 \\
\hline Source: data processed by researchers & $(2020)$
\end{tabular}

From table 3 Each of the independent variables has a significance value more than 0.1 , as can be shown. As a result, this model does not have any heteroscedasticity., or all independent variables have the same distribution of variants.

\subsection{Multicollinearity Test}

Multicollinearity test means to test whether the relapse model found a relationship between's the free factors (autonomous). A decent relapse model ought not have a relationship 
between's the free factors. Multicollinearity can be identified utilizing the Tolerance esteem and the Variance Inflation Factor (VIF) esteem. Multicollinearity doesn't happen in the event that the Tolerance esteem is under 0.10 and the VIF esteem is more prominent than 10 , as well as the other way around assuming the Tolerance esteem is more noteworthy than 0.10 and the VIF esteem is under 10 multicollinearity happens.

\begin{tabular}{|c|c|c|}
\hline \multirow{2}{*}{ Variable } & \multicolumn{2}{|c|}{ Collinearity Statistics } \\
\hline & Tolerance & VIF \\
\hline Budget Planning & 0.447 & 2.235 \\
\hline Performance Measurement System & 0.597 & 1.676 \\
\hline Budget Evaluation & 0.320 & 3.122 \\
\hline
\end{tabular}

Table 4 shows that there are no free factors with a resilience worth of under 0.10 and a VIF esteem, and no autonomous factors with a VIF esteem more prominent than 10 . Thus, no multicollinearity between the free factors in the relapse model still up in the air.

\subsection{Test of Autocorrelation}

The autocorrelation test is utilized to check whether there is a connection between puzzling blunders in period $t$ and frustrating mistakes in period $t-1$ in a direct relapse model (past). An autocorrelation issue happens when there is a connection. Since progressive perceptions all through time are attached to each other, autocorrelation happens. A respectable relapse model is one that doesn't get any autocorrelation. The Durbin-Watson (DW) test is utilized to decide if there is autocorrelation, with the presumption that assuming the DW test esteem is more prominent than the table worth, then, at that point, there is no autocorrelation.

Table 5. Autocorrelation Test Results

\begin{tabular}{ccc}
\hline Model & $\mathbf{R}$ & $\begin{array}{c}\text { Change Statistics } \\
\text { Durbin-watson }\end{array}$ \\
\hline 1 & $.860^{\mathrm{a}}$ & 1.600 \\
\hline Source: data processed by researchers (2020)
\end{tabular}

From table 5 above it can be seen that the DW value is 1,600 , this value is greater than the table value, namely the value of $\mathrm{dL}, \alpha=1.5830$, while the value of $\mathrm{dU}, \alpha=1.68667$, the value of $\mathrm{dU}, \alpha<\mathrm{dw}<4-\mathrm{dU}, \alpha$ so that It can be concluded that the residual does not contain autocorrelation.

\subsection{Hypothesis testing}

Hypothesis testing is used in research to assess whether or not hypotheses are valid. Several tests, including the determination coefficient test (R2), F test, t test, and regression analysis, are used in hypothesis testing with the use of SPSS 26 software.

a) Test for Determination Coefficient (R2)

The coefficient of determination is used to calculate the model's accuracy. is built, namely the contribution of the influence of the independent variables of Budget Planning (X1), Budget Evaluation (X2) and Performance Measurement (X3) on Performance (Y). 
Table 6. Coefficient Determinacy $\left(\mathrm{R}^{2}\right)$

\begin{tabular}{cccc}
\hline $\mathbf{R}$ & R Square & Adjusted R Square & Std. Error of the Estimate \\
\hline .860 & .740 & .730 & 2.833 \\
\hline \multicolumn{4}{c}{ Source: data processed by researchers $(2020)$}
\end{tabular}

Hypothesis testing is used in research to assess whether or not hypotheses are valid. The value of determination (adjusted R2) is 0.730 , as can be seen from these data. This suggests that the Budget Planning (X1), Performance Measurement (X2), and Budget Evaluation (X3) variables can explain 73 percent of the variation in the Performance variable $(Y)$. Other variables not included in the study influence the remaining $27 \%$. this study.

b) Simultaneous Significance Test / F Test

The F statistical test is used to see if all of the independent variables in the model have the same effect on the dependent variable. The table below shows the results of the F test calculation. below:

\begin{tabular}{cccc}
\multicolumn{4}{c}{ Table 7. Simultaneous F / Significance Test Results } \\
\hline Variable free & F Hitung & $\mathbf{F}_{\text {Tabel }}$ & Sig \\
\hline $\begin{array}{c}\text { Budget Planning (X1), Performance Measurement } \\
\text { System (X2) and Budget Evaluation (X3). }\end{array}$ & 71.198 & 2,15 & 0,000 \\
\hline \multicolumn{2}{c}{ Source: data processed by researchers (2020) } & & \\
\hline
\end{tabular}

The Fcount value is 71.198 , while the FTabel value is 2.15 , based on the results of the calculation in the table above. As a result, the independent variables Budget Planning (X1), Performance Measurement System (X2), and Budget Evaluation (X3) have a positive effect on the dependent variable Performance at the same time (Y).

\subsection{Partial Significance Test / T Test}

The $t$ statistical test is used to see how much each independent variable contributes to explaining the variation in the dependent variable. The table below shows the results of the $t$ test computation:

\begin{tabular}{lccc}
\multicolumn{4}{c}{ Table 8. Results of $t$ Test / Partial Significance Test } \\
\hline \multicolumn{1}{c}{ Variable free } & $\mathbf{t}_{\text {hitung }}$ & $\mathbf{t}_{\text {tabel }}$ & $\mathbf{t}_{\text {sig }}$ \\
\hline Budget Planning (X1) & 3,124 & 1,664 & 0,003 \\
Performance Measurement (X2) & 4,666 & 1,664 & 0,000 \\
Budget Evaluation (X3) & 3,624 & 1,664 & 0,001 \\
\hline
\end{tabular}

Source: data processed by researchers (2020)

According to the results of the research data processing, tcount (3.124) $>t$ table (1.664), then $\mathrm{Ha}$ is approved and $\mathrm{HO}$ is rejected, indicating that the independent variable of Budget Planning (X1) has a partial positive effect on the performance variable of the Directorate General of Budgeting. Defense Planning. tcount (4.666)> ttable (1.664) is obtained as a result of research data processing, therefore $\mathrm{Ha}$ is accepted and $\mathrm{HO}$ is rejected, resulting in the independent variable. The performance variable of the Directorate General of Defense Planning is partially influenced by the variable Performance Measurement System (X2). tcount $(3,624)>$ ttable $(1,664)$ is produced as a result of research data processing, then $\mathrm{Ha}$ is accepted and $\mathrm{HO}$ is denied, indicating that the independent variable is Ha. 
Budget Evaluation (X3) has a slightly beneficial impact on performance variable of the Directorate General of Defense Planning. In the evaluation it is also necessary to know that the tenure is the period of time or length of time an employee has devoted himself to a company or organization [22]. The work period is important for evaluation because it affects the experience of carrying out evaluation activities.

\section{Analysis of Multiple Linear Regressions}

In this review, relapse investigation is utilized to assess the connection between the reliant variable and the free factor determined to foresee or estimating the reliant variable's worth dependent on the autonomous variable. The following is a table of Coefficients got from handling information through the SPSS 26 programming.

Table 9. Coefficients untuk Regresi Linier Multiple

\begin{tabular}{lcc}
\hline \multirow{2}{*}{ Model } & \multicolumn{2}{c}{ Unstandardized Coefficients } \\
\cline { 2 - 3 } & B & Std. Error \\
\hline (Constant) & $-8,436$ & 3,421 \\
Budget planning & .310 & .099 \\
Performance measurement system & .538 & .115 \\
Budget evaluation & .590 & .163 \\
\hline
\end{tabular}

Source: data processed by researchers (2020)

The multiple linear regression equation (1) is as follows, based on the Coefficients table above:

$\mathrm{Y}=\mathrm{a}+\mathrm{b}_{1} \mathrm{X}_{1}+\mathrm{b}_{2} \mathrm{X}_{2}+\mathrm{b}_{3}+\mathrm{X}_{3}$

$Y=-8,436+0,310 X_{1}+0,538 X_{2}+0,590 X_{3}$

The following is an explanation and interpretation of the multiple linear regression equation:

$\mathrm{a}=$ The constant symbolized by "a" has a value of -8.436 . This means that if the Budget Planning variable (X1), the Performance Measurement System (X2) and Budget Evaluation (X3) is worth 0 (zero), then the Performance variable (Y) is worth $-8,436$ assuming the other variables are considered constant.

$\mathrm{b}_{1}=0.310$ states that whenever the Budget Planning variable (X1) rises by one unit, the Performance variable (Y) rises by 0.310, given the Performance Measurement System (X2) and Budget Evaluation (X3) remain constant. Furthermore, given the value of b1 (0.310) is positive, it may be concluded that Budget Planning (X1) has a positive impact on Performance (Y). This means that if the Budget Planning variable has a larger value, (the stronger it is, the better it is planned, the more consistency), the performance will also be higher, and vice versa.

$\mathrm{b}_{2}=0.538$ states that every time If the value of the Performance Measurement System (X2) variable increases by one unit, then Performance (Y) will increase by 0.538 , providing the Budget Planning (X1) and Budget Evaluation (X3) variables are both fixed in value. Furthermore, because b2 (0.538) is positive, it may be concluded that the Performance Measurement System (X2) variable has a positive impact on performance (Y). As a result, if the value of the Performance Measurement System variable is higher (the stronger it is, the better it is planned, the more consistent), then the performance will also be higher, and vice versa. $b_{3}=0.590$ states assuming the Budget Planning variable (X1) and the Performance 
Measurement System variable (X2) are both stable in value, every time the value of the Budget Evaluation variable (X3) increases by one unit, Performance (Y) increases by 0.590 . Furthermore, because b3 (0.590) is positive, it may be concluded that the Budget Evaluation variable (X3) has a positive impact on performance (Y). This means that if the Budget Evaluation variable's value is higher (the stronger it is, the better it is planned, the more consistent), then the performance will also be higher, and vice versa.

\section{Conclusion}

a. Budget planning partially has a favorable and significant impact on the Directorate General's performance Defense Planning, Ministry of Defense. It can be concluded that the higher (the better, the more consequent and consistent) the implementation of budget planning, the performance will increase, and vice versa.

b. The performance measurement system partially Having a strong and favorable impact on the Directorate General's performance Defense Planning, Ministry of Defense. It can be concluded that the higher (the more measurable, the better the available and consistent system) the implementation of the performance measurement system is, the performance will increase, and vice versa.

c. Budget evaluation partially Having a strong and favorable impact on the Directorate General's performance Defense Planning, Ministry of Defense. It can be concluded that the higher (the better the evaluation process, the more consequent and consistent) the implementation of the budget evaluation, the performance will increase, and vice versa.

d. Budget planning, performance measurement and budget evaluation together (simultaneously) have a favorable and significant impact on the performance of the Ministry of Defense's Directorate General of Defense Planning The Adjusted R Square value of 0.730 indicates that 73 percent of the variance is explained. The variables of budget planning, performance measurement, and budget evaluation can explain variation in performance factors in this study model. Other characteristics or variables that are not included in this research model influence the remaining $27 \%$.

There are various theoretical proposals for this research based on the discussion and conclusions in this study, including:

a. For further research: The variables used for this study are only three variables, therefore in future studies can add other variables related to organizational performance.

b. The researcher also realized that one of the limitations of this study was that it was not equipped with direct interviews with respondents, so that the respondents' answers were limited to the questions in the questionnaire. Therefore, researchers cannot explore all the things that are the purpose of the research in more depth.

\section{Acknowledgement}

The preparation of this thesis can be completed with the help and support of various parties, either directly or indirectly. On this occasion the researcher would like to thank:

a. Vice Admiral TNI Dr. A. Octavian, S.T., M.Sc., DESD., As Chancellor of the Defense University of the Republic of Indonesia; 
b. Vice Admiral TNI Dr. Kasih Prihantoro., S.E., M.M., M.Tr. (Han)., As Former Dean of the Faculty of Defense Management, Republic of Indonesia Defense University;

c. Dr. Aris Sarjito, S.IP., M.AP., IPU., CIQaR Colonel Laut (T) as Secretary of the Defense Management Study Program, Faculty of Defense Management, University of Defense of the Republic of Indonesia, as well as reviewer II in writing this thesis.

\section{References}

[1] Supandi. (2018). Ekonomi Pertahanan (Defense Economics) Panduan Studi Ilmu Pertahanan. Jakarta: Makmur Cahaya Ilmu.

[2] Yusgiantoro, P. (2014). Ekonomi Pertahanan. Jakarta: Gramedia Pustaka Utama.

[3] Saputro, g. e. (2021). Implementation of Economic Policies Facing Covid 19 in Supporting. International Journal of Social Science and Human Research, 634-642.

[4] Darmawan, C. (2013). Pendidikan Bela Negara dalam Konteks Keamanan Nasional dalam Muradi (ed.) Penataan Kebijakan Keamanan Nasional. Bandung: Dian Cipta.

[5] Saputro, g. e. (2020). THE IMPACT OF THE MILITARY EXPENDITURE AND SECURITY . jurnal pertahanan, 28-341.

[6] Saputro, g. e. (2019). Analisis Pengaruh Stabilitas Keamanan dan Pertumbuhan Industri Strategis . jurnal ekonomi.

[7] Indrawan, J., \& Widiyanto, B. (2017). Korupsi sebagai Bagian dari Perang Proxy: Upaya untuk Memberantas Bahaya Korupsi di Indonesia”, . Jurnal Pertahanan \& Bela Negara, Vol. 7, No. 1, 32-33.

[8] Saputro, g. e. (2021). THE ROLE OF DEFENSE ECONOMIC IN ECONOMIC GROWTH. Jurnal Pertahanan Unhan, 330-341.

[9] Aribawa, Y., Rachmina, D., \& Falatehan. (2018). Strategi Peningkatan Implementasi Anggaran Berbasis Kinerja Pada Ditjen Anggaran Kementerian Keuangan. Jurnal Manajemen Pembangunan Daerah. Volume 10 Nomor 1, 25-34.

[10] Azwar. (2016). Allocative Role of Government through Procurement of Good/Service and its Impact on Indonesian Economy. Kajian Ekonomi Keuangan. Volume 20 Nomor 2.

[11] Saputro, g. e. (2021). Pengaruh Stabilitas Makro Ekonomi, Stabilitas Keamanan Dan Pertumbuhan Industri . jurnal ekonomi universitas borobudur.

[12] Saputro, g. e. (2021). PENGARUH ANGGARAN PERTAHANAN, IMPOR ALUTSISTA, EKSPOR DAN INFLASI TERHADAP PERTUMBUHAN EKONOMI. JURNAL EKONOMI UNIVERSITAS BOROBUDUR

[13] Sugiyono. (2019). Metode Penelitian Kuantitatif, Kualitatif dan R\&D. Bandung: Alfabeta.

[14] Sugiyono. (2019). Statistika untuk Penelitian. Bandung: Alfabeta.

[15] Kuncoro, M. (2013). Metode Riset untuk Bisnis \& Ekonomi Edisi 4. Jakarta: Erlangga.

[16] Ghozali, I. (2018). Aplikasi Analisis Multivariate dengan Program IBM SPSS 25 Edisi 9. Semarang: Badan Penerbit Undip.

[17] Hudayati, A. (2002). Perkembangan Penelitian Akuntansi Keperilakuan: Berbagai Teori Dan Pendekatan Yang Melandasi. JAAI Volume 6, Nomor 2, 81-96.

[18] Kusuma, I. G. (2014). Pengaruh Kejelasan Sasaran Anggaran, Komitmen Organisasi dan Ketidakpastian Lingkungan pada Ketepatan Anggaran (Studi Empiris di SKPD Pemerintah Provinsi Bali. E-Journal Ekonomi dan Bisnis Universitas Udayana. Volume 03 nomor 3, 154-165. 
[19] Suwaryo, Widyaswara, P. A., \& Yuwono. (2017). (). "Faktor-Faktor Yang Mempengaruhi Tingkat Pengetahuan Masyarakat dalam Mitigasi Bencana Alam Tanah Longsor". The 6th University Research Colloquium 2017 Universitas Muhammadiyah Magelang, 305-314.

[20] Ukas, I. (2017). Faktor-Faktor Yang Mempengaruhi ProduktivitasTenaga Kerja Industri Kecilkota Palopo. Journal of Islamic Education Management. Volume 2, Nomor 2 , 187-198.

[21] Munawar, Irianto, \& N., G. (2006). Pengaruh Karakteristik Tujuan Anggaran Terhadap Perilaku, Sikap, Dan Kinerja Aparat Pemeirntah Daerah Di Kabupaten Kupang. Simposium Nasional Akuntansi 9 Padang 23-26 Agustus 2006, 1-45.

[22] Kurniawati, I. D. (2014). Masa Kerja Dengan Jobengagement Pada Karyawan . Jurnal Ilmiah Psikologi Terapan. Volume 02, Nomor 02, 311-324. 